\title{
Neck Surgery versus Neck Immunology
}

\author{
Ibrahim M S A W Shnawa* \\ College of Biotechnology, University of Qasim, Iraq
}

Submission: July 11, 2017; Published: July 17, 2017

*Corresponding author: Ibrahim M S A W Shnawa, College of Biotechnology, University of Qasim, Iraq, Email: Ibrahimshnawa3@gmail.com

\section{Opinion}

Smart Surgeon [1] should be smart anatomist and smart physiologist. This theme seems to be deficient unless immunologist similarly should have good knowledge in anatomy and physiology. The link between surgeon and immunologist is through the anatomy and physiology. Hence the trigon of head neck and spine surgery appeared to be linked to immunology through anatomy and physiology. Among this trigon neck perceive my personal attention, since it got several biologic bearings like terato-biology, structural and functional immunology (Table 1-3) [2-5]. So far the structural immunologic aspects is concerned it served as a niche for tonsils, cervical lymph node and passage way for cervical lymphatics. While for functional immunology it served as stage for natural immune drain for microbial invadors coming from mouth, oropharynx and dental infections as well as tonsils. The draining lymph nodes also drain aberrant overgrowing cancer cells arisen in the neck area.

Table 1: Neck Biology.

Functional Anatomy: Head support, Passage of blood and lymph vessels, niche for lymph glands and nerve passages

Astheticbiology: Neck is being as a source of female beauty when it is long and slime.

Teratobiology: neck malformation mostly congenital events are merely seen but need surgical interplay.

Table 2: Immunology of Neck [2].

Structural Immunology: It serves as anatomic niche for the mucosal lymph glands the tonsils and secondary lymph glands the cervical lymph nodes.

Functional Immunology: Natural immune drain of oral, dental and laryngeal microbial and neoplastic invading cells. Besides the possible graft versus host reactions in case of improper tissue grafts.
Neck surgeon inter played real important roles for the immune state of neck area including removal of neoplasms of lymphoid tissues, infective granulomas, chronic cervical lymphadenopathy and space occupying lesions and performing eligible tissue grafting. While the interplay roles of immunologist for the neck region furnishing the basics for mucosal immune function [6], tissue transplantation, immunology of granuloma, immune diagnosis for disorders, mechanisms of natural immune drainage of invaders (Table 2-4).

Table 3: The interplay of neck surgeon for immunologist[1]

\begin{tabular}{|c|}
\hline A-Management of \\
\hline 1-neck lymphoid neoplasms \\
\hline 2-Infective granulomas \\
\hline 3-infectious space occupying lesions \\
\hline 4-Chronic lymphoadenpathy \\
\hline 5-Sepsis And Septic Syndrome \\
\hline B-Performing \\
\hline 6-Eligible tissue grafts \\
\hline
\end{tabular}

Table 4: The interplay of immunologist to neck surgeon [2-6].

\begin{tabular}{|c|}
\hline Provides Basics for \\
\hline 1-Mucosal immune functions. \\
\hline 2-Tissue transplantation and mechanisms of tissue graft rejections. \\
\hline 3-immunology of granulomas \\
\hline 4-Mechanism of natural immune drainage of secondary lymph glands \\
\hline 5-Immunopathologic Mechanisms of chronic lymphadenopathy \\
\hline 6-Transfusion \\
\hline 7-Cancer Immunotherapy
\end{tabular}




\section{References}

1. (2013) Head and Neck Surgery. In: Har EI, Day TA, Nathan CAO, Nguyen SA (Eds.), $1^{\text {st }}(\mathrm{edn})$, Theime, UK, p. 498.

2. Alexander JW (2013) Surgical Immunology and the development of Modern Surgery. Int J Surg 11: S6-S7.

3. Jane Shelby (1991) Immunology in Surgical Practice. In: Pollock A, Arnold E (Eds.), Cell Press, USA, p. 393.
4. (2002) Immunology For Surgeons. In: Zbar AP, Guillon PJ, Bland KI, Syrigos KN (Eds.), Spriger Publishing, USA.

5. (2011) Essential Immunology for Surgeons. In: Ermin O, Sewell H (Eds.), Oxford University Press, India.

6. Shnawa I MS AW (2017) Otolyrengologic Mucosal Immune Compartments. OOAJ 2(1): 000147.

\section{Your next submission with Juniper Publishers will reach you the below assets}

- Quality Editorial service

- Swift Peer Review

- Reprints availability

- E-prints Service

- Manuscript Podcast for convenient understanding

- Global attainment for your research

- Manuscript accessibility in different formats

( Pdf, E-pub, Full Text, Audio)

- Unceasing customer service

Track the below URL for one-step submission https://juniperpublishers.com/online-submission.php 